\begin{tabular}{|c|c|}
\hline Jupnal Kesmas Untika Luwuk: Public Health Journa & KESMAS \\
\hline Volume 11, Nomor 2, Desember 2020 & \\
\hline P-ISSN: 2086-3773, E-ISSN: 2620-8245 & \\
\hline Website: https://journal.fkm-untika.ac.id/index.php/phj & \\
\hline This work is licensed under a Creative Commons Attribution 4.0 International License. & $8=$ \\
\hline
\end{tabular}

\title{
Upaya Pemerintah Desa Terhadap Penanggulangan Stunting di Wilayah Kerja Puskesmas Totikum Selatan Kabupaten Banggai Kepulauan
}

(Village Government Efforts to Tackle Stunting in The Working Area of Totikum Selatan Health Center Banggai Kepulauan)

\author{
Mirawati Tongko ${ }^{1}$, Erik Pradana Budi ${ }^{1}{ }^{*}$, Herawati $^{1}$, Marselina Sattu $^{1}$ \\ ${ }^{1}$ Fakultas Kesehatan Masyarakat Universitas Tompotika Luwuk \\ *Koresponden Penulis : erikpradanabudi@gmail.com
}

\begin{abstract}
ABSTRAK
Kejadian stunting berdasarkan data Riskesdas Tahun 2018, Provinsi Sulawesi Tengah sebesar 32,5\%, Kabupaten Banggai Kepulauan sebesar 6,16\%, sementara untuk Puskesmas Totikum Selatan sebesar $18 \%$. Adapun tujuan dari penelitian ini adalah untuk memperoleh gambaran upaya pemerintah Desa terhadap penanggulangan stunting di Wilayah Kerja Puskesmas Totikum Selatan Kabupaten Banggai Kepulauan. Jenis penelitian menggunakan metode kualitatif. Teknik penentuan informan yaitu secara purposive samping sehingga informan dan infroman kunci adalah kepala desa, bidan,kader, kepala puskesmas,tokoh masyarakat, DMPDA. Analisis data penelitian melalui 3 alur yaitu : Data reduction, Data Disply, dan conclusion darwing/Verifikstion. Hasil penelitian menunjukan bahwa bentuk upaya pemerintah desa terhadap penanggulangan stunting dalam hal peningkatan gizi masyarakat yaitu dengan pemberian makanan tambahan pada balita dan lansia, sedangkan dalam hal sanitasi berbasis lingkungan yaitu telah diupayakannya pengadaan sarana jamban dan air bersih pada setiap desa, selain itu sudah ada dalam rencana APBdes untuk peningkatan anggaran dalam penyelengaraan jamban sehat, serta pembangunan air minum dan sanitasi yang sudah mencapai $100 \%$. Pemberdayaan masyarakat dilakukan dengan peningkatan pengetahuan melalui kerja sama dengan pihak puskesmas yang melibatkan pemerintah desa beserta tokoh masyarakat untuk upaya peningkatan pengetahuan tentang stunting, serta masyarakat berperan aktif untuk mengikuti program kesehatan dalam upaya peningkatan pengetahuan masyarakat. Adapun saran yaitu perlu adanya pemantauan berkala dari pemerintah daerah terhadap kegiatan-kegiatan penanggulangan stunting yang dilakukan oleh setiap pemerintah Desa yang ada.
\end{abstract}

\section{Kata Kunci: Pemerintah Desa, penanggulangan, stunting}

\begin{abstract}
The incidence of stunting based on data from Riskesdas in 2018, Central Sulawesi Province was $32.5 \%$, Banggai Islands Regency was 6.16\%, while for South Totikum Health Center it was 18\%. The purpose of this study was to obtain an overview of the efforts of the Village government to tackle stunting in the Work Area of the South Totikum Health Center, Banggai Islands Regency. This type of research uses qualitative methods. The technique of taking informants was purposive side to side so that key informants and informants were the village head, midwives, cadres, heads of puskesmas, community leaders, DMPDA. Analysis of research data through 3 channels, namely: Data reduction, Data Disply, and conclusion darwing / verification. The results showed that the form of village government efforts to tackle stunting in terms of improving community nutrition is by providing additional food for toddlers and the elderly, while in the case of environmental-based sanitation, namely the provision of latrines and clean water facilities in each village, besides that it is already in place. APBdes plans to increase the budget for the implementation of healthy latrines, as well as the construction of drinking water and sanitation which has reached 100\%.
\end{abstract}


Upaya Pemerintah Desa ... (Tongko, Budi dan Herawati) $\mid 57$

Community empowerment is carried out by increasing knowledge through collaboration with the community health center which involves the village government and community leaders to increase knowledge about stunting, and the community plays an active role in participating in health programs in an effort to increase community knowledge. The suggestion is that there is a need for regular monitoring from the local government of the stunting prevention activities carried out by each existing Village government.

\section{Key Word: Village government, prevention, stunting}

\section{PENDAHULUAN}

Pembangunan kesehatan Indonesia dalam periode tahun 2015-2018 difokuskan pada empat program prioritas yaitu penurunan angka kematian ibu dan bayi, penurunan prevalensi balita pendek (stunting), pengendalian penyakit menular dan pengendalian penyakit tidak menular. Upaya peningkatan status gizi masyarakat termasuk penurunan prevalensi balita pendek menjadi salah satu prioritas yang tercantum di dalam sasaran pokok Rencana Pembangunan Jangka Menengah Tahun 2015-2018 (RPJMN, 2015-2018). Target penurunan prevalensi stunting (pendek dan sangat pendek) pada anak baduta (dibawah 2 tahun) adalah mencapai $28 \%$ (Kemkes RI, 2016).

WHO menetapkan batas toleransi stunting (bertubuh pendek) maksimal 20\% atau sperlima dari jumlah keseluruhan balita. Sementara, di Indonesia tercatat 7,8 juta dari 23 juta balita adalah penderita stunting atau sekitar 35,6\%. Sebanyak 18,5\% kategori sangat pendek dan 17,1\% kategori pendek. Ini juga yang mengakibatkan WHO menetapkan Indonesia sebagai negara dengan status gizi buruk. Di Indonesia, pada tahun 2010 sekitar 35,6\% anak balita mengalami stunting, sedangkan tahun 2013 meningkat menjadi 37,2\% dan di tahun 2018 terus menurun hingga 23, 6\% (Kementerian Kesehatan RI Badan Penelitian dan Pengembangan, 2018).

Berdasarkan data Riskesdas Tahun 2018, diketahui bahwa Provinsi Sulawesi Tengah Sebesar 32,5\% untuk kejadian stunting. Sedangkan prevalensi kejadian stunting di Kabupaten Banggai Kepulauan yaitu sebesar 6,16\% sementara untuk Puskesmas Totikum Selatan yaitu sebesar 18\% (Bangkep, 2019).

Peran Pemerintah Daerah terhadap penanggulangan stunting ini adalah mencanangkan Gerakan Nasional percepatan perbaikan gizi yang di tetapkan melalui Peraturan Presiden Nomor 42 tahun 2013 Gernas PPG dalam kerangka 1.000 Hari Pertama Kelahiran (HPK). Sehingganya dari situ indikator dan target penurunan stunting telah dimasukkan sebagai sasaran Pembangunan Nasional dan tertuang dalam Rencana Pembangunan Jangka Menengah Nasional 2015-2019 dan Rencana Aksi Nasional tujuan pembangunan berkelanjutan 2017-2019. Atas hal itu, pemerintah daerah melakukan intervensi-intervensi dengan memasukan program dan kegiatan terkait pada dokumen perencanaan seperti RPJMD Provinsi Suawesi Tengah tahun 2016-2021 yang saat ini dalam proses perubahan.

Sehingga penelitian ini bertujuan untuk mengetahui upaya Pemerintah Desa terhadap penanggulangan stunting di wilayah kerja Puskesmas Totikum Selatan Kabupaten Banggai Kepulauan. 

58 | Jurnal Kesmas Untika: Public Health Journal, 11 (2): 56-61

\section{METODE PENELITIAN}

Jenis Penelitian yang dilakukan adalah penelitian kualitatif dengan menggunakan pendekatan Etnometodologi yaitu memusatkan kajian pada realita yang memiliki penafsiran praktis (meen atau makna pada perilaku nyata). Etnometodologi mengacu pada suatu studi bagimana seorang individu dalam masyarakat bertindak dan berkreasi serta memahami hidup keseharian mereka (Bungin, 2011).

Penelitian ini dilaksanakan di wilayah kerja Puskesmas Totikum Selatan Kabupaten Banggai Kepulauan di delapan desa di wilayah kerja Puskesmas Totikum Selatan Kabupaten Banggai Kepulauan yaitu desa: Desa Kalumbatan, Desa Kanali, Desa Peley, Desa Tobungku, Desa, Lobuton, Desa Nolion, Desa Mata, Desa Tonuson. Waktu penelitian pada bulan Juli tahun 2020.

Pengumpulan data dalam penelitian ini dilakukan melalui wawancara mendalam (indepth interview) terhadap informan dimana instrumen penelitian adalah peneliti sandiri yang di lengkapi dengan alat bantu penelitian, seperti alat perekam wawancara, pedoman wawancara, dan catatan lapangan (field note).

\section{HASIL}

\section{Peningkatan Gizi Masyarakat}

Hasil wawancara dengan informan tentang upaya pemerintah desa terhadap penanggulangan stunting yang telah di lakukan masyarakat dengan membangun kerja sama bersama pemerintah desa dan pihak terkait. Dari 55 orang informan sebanyak 31 ungkapan informan biasa orang yang sama sebagai berikut:

“Upayanya itu pemberian makanan tambahan balita dan lansia baru pengadaaan obatobatan bagitu, kalo untuk dana stunting itu masih perubahan APBdes torang, jadi bulum $d i$ tau $d p$ dana stunting tapi memang ada dia punya dana

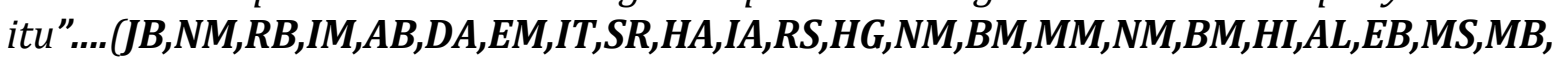
$H I, M N, H Y, H N, N H, S S, S B, H B, S H, S I, A B, F B, N L, S U, N I, N S$,)

\section{Sanitasi Berbasis Lingkungan}

Hasil wawancara dengan informan tentang sanitasi berbasis lingkungan di desa, dari 55 orang informan sebanyak 14 orang ungkapan informan biasa yang sama seperti dalam ungkapaan sebagai berikut:

"Kalau torang itu dari masalah kebersihan seperti WC, pengadaan air bersih juga itu torang adakan"..(IM,NM,HA,IT,NH,HN,SS,SB,BM,HI,NM,AI,EB,NS)

\section{Peningkatan anggaran dalam penyelenggaraan jamban sehat.}

Hasil wawancara dari 55 orang informan, sebanyak 13 orang ungkapan informan biasa yang sama tentang bagiamana upaya pemerintah desa terhadap jamban sehat di desa, sebagai berikut:

"Untuk sementara bulum ada karna masih ada perubahan APBdes baru jadi bulum di tau, tapi untuk anggarannya ada itu hanya kami melakukan perubahan ini"...(NM,DA,IT,RS,BM,HI,NM,AI,EB,FB,NL,SU,NI) 
Upaya Pemerintah Desa ... (Tongko, Budi dan Herawati)| 59

\section{Pembangunan air minum dan sanitasi}

Hasil wawancara dari 55 orang informan, sebanyak 25 orang informan biasa yang sama tentang bagaimana peran pemerintah desa terhadap pembangunan air minum, seperti ungkapan informan sebagai berikut:

"Untuk Pembangunan air minum itu sudah ada kalua desa $100 \% " . .(N M, I M, N D, A B, I T, H A, N M, B M, H I, N M, A I, E B, N H, H N, S S, S B, R K, K M, M N, H B, S H, S I, A B$, IA,NS)

\section{PEMBAHASAN}

\section{Peningkatan gizi masyarakat}

Kepala Desa merupakan individu yang menjadi pemimpin di Desa, Kepala Desa bertanggung jawab penuh atas roda pemerintahan, pembangunan, pemberdayaan masyarakat yang ada di Desa. Selain pemerintahan dalam roda pemerintahan, Kepala Desa juga memiliki peranan penting dalam pembangunan yang ada di Desa terutama dari sektor kesehatan. Salah satu upaya membangun kesejahtaraan masyarakat dengan merangkul nilai-nilai sosial saat ini yaitu melalui pemberdayaan masyarakat. Pemberdayaan masyarakat sebagai pelaku dan penerima atau objek dan subjek manfaat dari proses mencari solusi dan meningkatkan kesejahtaraan dari hasil pembangunan.

Dari hasil penelitian wawancara mendalam dengan informan bahwa bentuk peningkatan gizi masyarakat dalam pencegahan stunting yang dilakukan oleh Pemerintah Desa Totikum Selatan yaitu menganggarkan setiap tahunnya untuk dana stunting, adapun upaya dalam hal memenuhi perkembangan gizi balita yaitu pemberian makanan tambahan bagi balita setiap bulannya melalui kegiatan posyandu yang ada di Desa dan ditambah dengan kegiatan pemeriksaan kesehatan pada anak balita secara rutin setiap bulannya. Untuk peningkatan gizi masyarakat serta pencegahan stunting, Pemerintah Desa memanfaatkan dana Desa untuk penyedian air bersih dan sanitasi, pemberian makanan dan bergizi untuk balita, pelatihan dan pemantauan perkembangan kesehatan ibu hamil atau menyusui, bantuan posyandu, pengembangan apotik hidup Desa dan produk hortikultura, serta pengembangan ketahanan pangan.

\section{Sanitasi Berbasis Lingkungan}

Sistem Penyedian Air Minum (SPAM) adalah suatu kesatuan sistem fisik yang (teknik) dan non fisik dari prasarana dan sarana air minum. Aspek teknis terdiri dari unit air baku, unit produksi, unit distribusi dan unit pelayanan sedangkan aspek non fisik teknis mencakup keuangan, sosial dan institusi.

Dari hasil penelitian ini diperoleh informasi bahwa upaya pencegahan stunting dalam hal sanitasi berbasis lingkungan yaitu Pemerintah Desa membantu pelaksanaan program kesehatan yaitu bekerjasama dengan stakeholder melakukan pelatihan kepada masyarakat dalam hal pengelolaan sarana sanitasi pada masing-masing rumah tangga. Hal ini bertujuan untuk meningkatkan kesadaran masyarakat tentang pentingnya sarana sanitasi yang memenuhi syarat kesehatan.

Pembagunan sarana sanitasi Desa dapat dilakukan dengan mudah mengingat ketersedian lahan yang lebih luas dibandingkan lahan yang ada diperkotaan apalagi didukung dengan dana Desa yang dapat digunakan untuk pembangunan fisik sarana sanitasi lingkungan, maupun dalam bidang pemberdayaan masyarakat Desa. Namun dalam tatanan rumah tangga, pengelolaan sanitasi lingkungan sangat dipengaruhi oleh 
kesadaran anggota keluarga, sehingga perlu upaya menggugah kesadaran masyarakat Desa akan pentingnya pengendalian sanitasi lingkungan, jika dibandingkan dengan pembangunan fisik sistem sanitasi itu sendiri.

\section{Peningkatan anggaran dalam penyelenggaraan jamban sehat}

Pendekatan perubahan perilaku hygiene dan sanitasi secara kolektif melalui pemberdayaan masyarakat dengan metode pemicuan. Langkah awal perubahan perilaku dengan pemicuan untuk meningkatkan akses terhadap akses sarana sanitasi yang di fasilitasi oleh pihak diluar komunitas sehingga masyarakat dapat mengambil keputusan untuk meningkatkan akses sarana jamban sesuai analisa kondisi lingkungan tempat tinggal dan resiko yang dihadapinya tanpa subsidi dari luar.

Hasil penelitian menunjukkan bahwa informan menjelaskan tentang upaya peningkatan anggaran jamban lewat APBdes, selain itu upaya lain yang dilakukan oleh Pemerintah Desa agar masyarakat mau membangun jamban sehat yaitu salah satunya dengan mengadakan arisan jamban. Arisan ini harus diikuti oleh kepala keluarga baik yang sudah mempunyai jamban sehat maupun yang belum mempunyai jamban sehat, dengan prioritas yang belum memiliki jamban sehat dapat arisan duluan berupa paket jamban sehat (sebagai bentuk kepedulian) sedangkan yang sudah mempunyai jamban sehat dapat berupa uang yang nantinya bisa digunakan untuk pengadaan atas perbaikan sanitasi lainnya. Dengan adanya arisan jamban ini diharapkan adanya partisipasi masyarakat untuk peduli terhadap lingkungan sehingga tercipta lingkungan yang bersih dan sehat.

\section{Pembangunan Sumber air minum dan sanitasi}

Salah satu upaya untuk mengatasi masalah ketersedian air dan penerunan derajat kesehatan lingkungan masyarakat akibat kondisi prasarana sanitasi yang buruk di pedesaan yaitu dengan Program Penyedian Sarana Air Minum dan Sanitasi Berbasis Masyarakat (PANSIMAS) yang di dukung oleh Kementrian Pekerjaan Umum dan Kementrian Kesehatan. Sesuai dengan tuntutan paradigma baru tentang pembangunan yang berpusat pada manusia (people centred development) maka pendekatan bottomup planning sudah sewajarnya di perbesar dan menjadi inti dari proses pembangunan yang memberdayakan masyarakat. Program PANSIMAS menggunakan paradigma pembangunan yang menitikberatkan pada startegis pembangunan dari bawa ke atas yang didasarkan pada mobilitasi sumber daya manusia, alam dan kelembagaan dengan tujuan memenuhi kebutuhan dasar masyarakat.

Hasil penelitian ini menunjukkan bahwa upaya pencegahan stunting oleh Pemerintah Desa dalam hal pembangunan air minum dan sanitasi yaitu pemerintah desa telah mengadakan PANSIMAS sehingga untuk pembangunan air minum di masingmasing desa sudah $100 \%$

\section{KESIMPULAN DAN SARAN}

Berdasarkan hasil penelitian yang diperoleh dapat ditarik kesimpulan bahwa upaya pemerintah desa terhadap penanggulangan stunting yang dilakukan di Wilayah Kerja Puskesmas Totikum Selatan Kabupaten Banggai Kepulauan tahun 2020 sebagai berikut:

1. Dalam hal peningkatan gizi masyarakat yaitu melakukan kegiatan pemberian makanan tambahan pada balita setiap bulannya melalui kegiatan posyandu. 

Upaya Pemerintah Desa ... (Tongko, Budi dan Herawati) $\mid 61$

2. Untuk hal sanitasi berbasis lingkungan, upaya yang dilakukan adalah melakukan pelatihan dan pemberian pengetahuan dalam upaya pencegahan stunting dengan sasaran pemerintah desa dan stakeholder yang terkait seperti petugas kesehatan, kader, tokoh agama, tokoh masyarakat.

3. Dalam hal peningkatan anggaran dalam penyelenggaraan jamban sehat yaitu dengan membuat program arisan jamban oleh masyarakat.

4. Untuk hal pembangunan air minum dan sanitasi, upaya yang telah yang dilakukan oleh pemerintah desa adalah dengan pembangunan Pamsimas yang 100\% Desa telah tersedia.

Adapun saran dalam penelitian ini yaitu meningkatkan kemitraan antara pemerintah desa dan puskesmas dalam hal pemberian makanan tambahan pada balita, perlu adanya tambahan anggaran dari pemerintah daerah dalam penyediaan sarana air bersih dan sanitasi yang ada di desa, perlu dibentuk STBM tingkat Desa yang melibatkan lintas sektor, dan perlu adanya pemantauan berkala dari pemerintah daerah terhadap kegiatan-kegiatan penanggulangan stunting yang dilakukan oleh setiap pemerintah Desa yang ada.

\section{UCAPAN TERIMA KASIH}

Terima kasih peneliti ucapkan kepada Pemerintah Daerah dan Pemerintah Desa Kecamatan Totikum Selatan Kabupaten Banggai Kepulauan sebagai lokasi penelitian.

\section{DAFTAR PUSTAKA}

Bangkep, D. (2019). Dinas Kesehatan Kabupaten Banggai Kepulauan (Vol. 14, Issue 45, p. 19690706). https://dinkes.lampungprov.go.id/covid19/

Bungin, B. (2011). Penelitian Kualitatif: Komunikasi, Ekonomi, Kebijakan Publik, Dan Ilmu Sosial Lainnya. In Kencana.

Kementerian Kesehatan RI Badan Penelitian dan Pengembangan. (2018). Hasil Utama Riset Kesehatan Dasar. Kementrian Kesehatan Republik Indonesia, 1-100. http://www.depkes.go.id/resources/download/info-terkini/hasil-riskesdas2018.pdf

Kemkes RI. (2016). Infodatin Pusat Data Informasi Kementrian Kesehatan Republik Indonesia. In Report. 